\title{
VRTBY ICHNORODU GASTROCHAENOLITES JAKOŽTO ŽIVOTNÍ PROSTOR MLŽŮ Z LOKALITY BORAČ-PODOLÍ (KARPATSKÁ PŘEDHLUBEŇ, ČESKÁ REPUBLIKA)
}

\author{
Borings of the ichnogenus Gastrochaenolites as a living space of bivalves from the locality \\ Borač-Podolí (Carpathian Foredeep, Czech Republic)
}

\author{
Jaroslav Šamánek ${ }^{1}$, Radek Mikuláš², Nela Doláková', Šárka Hladilová' \\ ' Ústav geologických věd PřF MU, Kotlářská 2, 61137 Brno \\ ${ }^{2}$ Geologický ústav AV ČR, v. v. i., Rozvojová 269, 16502 Praha 6
}

Key words: Carpathian Foredeep, Miocene, Badenian, Gastrochaenolites, bivalve borings

\begin{abstract}
In 2015 the locality Borač-Podoli was newly examined. The locality is situated $8 \mathrm{~km} \mathrm{NW}$ from the town of Tišnov. A large amount of shallow-water fossils of middle Miocene (Badenian) age was collected. The state of preservation of the material enabled us bivalve borings of ichnogenus Gastrochaenolites which were bored into colonies of hermatype corals and other calcareous hard substrates. In some of these borings, bivalves were found in situ. The borings were determined as Gastrochaenolites isp., Gastrochaenolites orbicularis, Gastrochaenolites lapidicus, Gastrochaenolites dijugus and Gastrochaenolites torpedo. The in situ bivalves were determined as Gastrochaena $c f$. intermedia, Rocellaria $c f$. dubia, Hiatella arctica and Cardita calyculata. The first three species probably represent primary borers while Cardita calyculata is probably a secondary user (squatter). Based on an analysis of fossil material, we can assume that borings were created after the death of corals during the repeated transport of these bioclasts. It led to colonizing of the whole surface of coral bioclasts. The bioclasts were then moved to deeper water. Transport to water with clay sedimentation enabled the preservation of the bivalves in situ in borings.
\end{abstract}

Úvod

$\mathrm{V}$ minulosti bylo z prostoru karpatské předhlubně popsáno několik výskytů miocenních vrteb mlžů na pevných substrátech. Poprvé si těchto vrteb všiml Augusta (1938), který měl $k$ dispozici korálovou kolonii z dnes již zaniklé lokality Jevíčko. Augusta předpokládal, že původci vrteb by měli být mlži rodu Lithophagus, ale fyzický důkaz v podobě in situ mlžů neměl. Materiálu z Jevíčka se také věnovali Mikuláš et al. (1999). Další nálezy popisuje Mikuláš a Pek (1995) z prostoru Hranic na Moravě. Vrtby byly nalezeny ve vápencích paleozoického

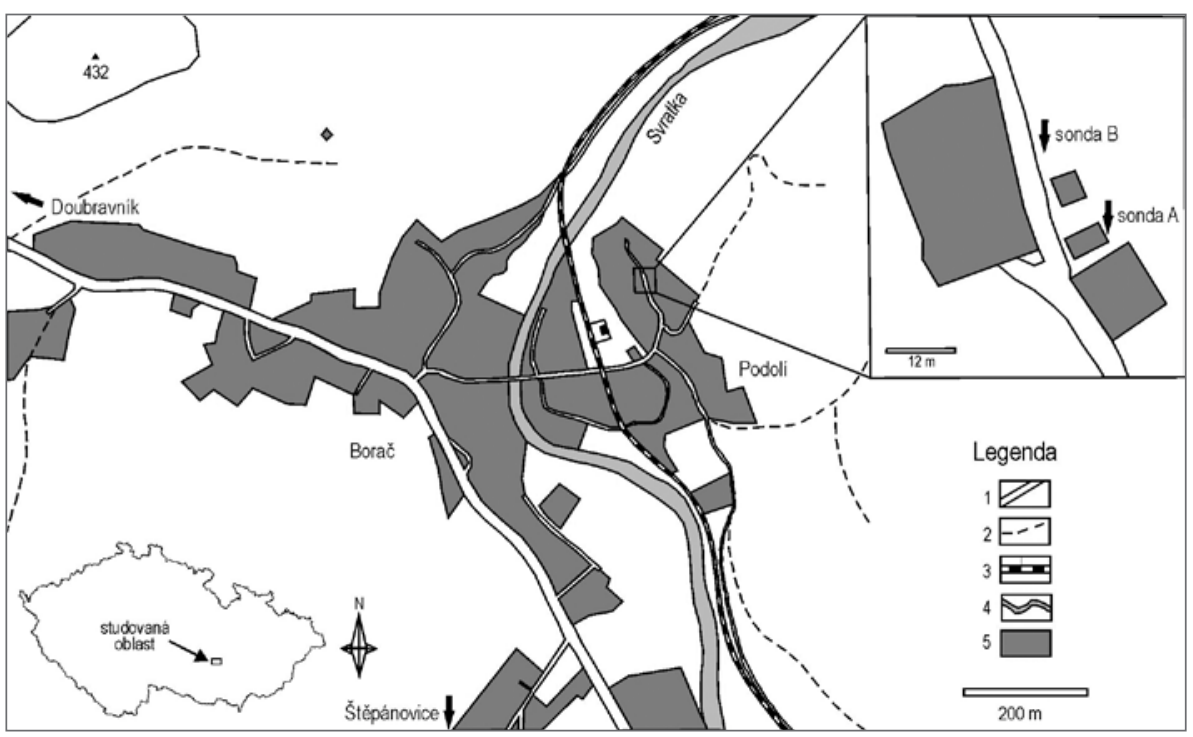

Obr. 1: Pozice studované lokality v obci Borač-Podolí. 1 - komunikace; 2 - cesta; 3 - železnice; 4 - řkek; 5 - obydlená plocha.

Fig. 1: Position of the studied locality in Borač-Podolí village. 1 - road; 2 - path; 3 - railway; 4 - river; 5 - inhabited area. stáríi. Další popsané vrtby

z devonských vápenců pochází od Čelechovic na Hané (Pek et al. 1998), Předmostí (Lehotský, Jašková 2005) a od Černotína (Janoška et al. 1995). Pek a Mikuláš (1996) podávají zprávu o obdobných stopách po vrtavých mlžích také z České Třebové, kde byly nalezeny ve vápnitých slínovcích. Lehotskýa Jašková (2005) informují o vrtbách

$\square$ Samanek.j@mail.muni.cz

DOI: https://doi.org/10.5817/GVMS2018-1-2-49 z kulmských prachovců od Seloutek. Z prostoru vídeňské pánve popisuje Pek a Mikuláš (1999) vrtby z vápencových valounů od Kinberka u Mikulova. V žádném $z$ výše uvedených př́padů nebyli nalezeni vrtaví mlži in situ. $\mathrm{V}$ předložené práci se autoři zaměřují na popis vrtavých mlžů nalezených ve vlastních vrtbách a na vrtby samotné.

V prímém okolí lokality se vyskytují metamorfované horniny moravika (pararuly, ortoruly, amfibolity) a kvartérní deluviální, fluviální a eolické sedimenty. Nedaleko od obce Borač směrem na SZ podél silnice 
na Doubravník je známý výskyt vápnitých jílů s bohatou faunou spodního badenu (např. Seitl 1978).

\section{Materiál a metody}

S laskavým svolením majitele byly na podzim roku 2015 provedeny terénní práce na pozemku zahrady přidružené k rodinnému domu (obr. 1). Terénní práce byly provedeny J. Šamánkem a L. Kleprlíkovou za pomoci dalších kolegů z Ústavu geologických věd Masarykovy univerzity a Moravských naftových dolů. V prostoru zahrady byly postupně ručně vykopány dvě sondy $(\mathrm{A}, \mathrm{B})$ o přibližné hloubce $2 \mathrm{~m}$. Sonda A byla situována za v. stěnou garáže ve svahu (N 49²4‘6,031“ E 16²2‘2,864“). Ačkoliv byly odkryty miocenní sedimenty, neobsahovaly makrofaunu. Proto byla vyhloubena sonda B. Ta se nacházela v blízkosti sloupu elektrického vedení, asi 1,5 m

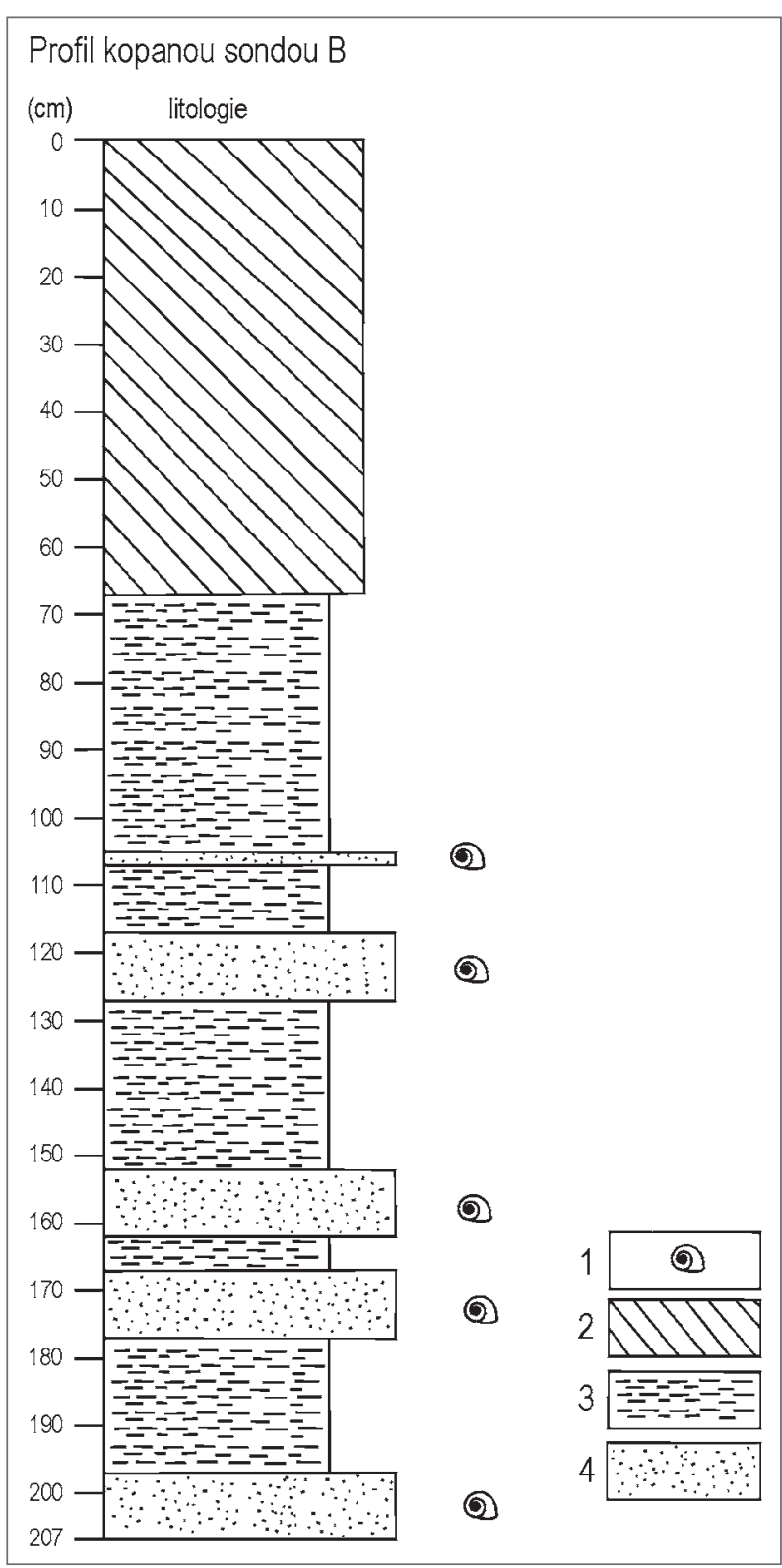

Obr. 2: Profil kopanou sondou B. 1 - fosiliferní vrstva; 2 - kvartérní pokryv; 3 - vápnitý jíl; 4 - křemitý písek.

Fig. 2: Schematic column of the probe B. 1 - fossiliferous layer; 2 - Quaternary cover; 3 - calcareous clay; 4 - quartzose sand. směrem na SSZ (N 49²4‘6,509“ E $\left.16^{\circ} 22^{\prime} 2,434^{\prime \prime}\right)$ a byla orientována paralelně s komunikací, která vede podél pozemku. Výškový rozdíl mezi sondami byl cca $1 \mathrm{~m}$. Kopaná sonda (obr. 2) odkryla střídání mocnějších vrstev vápnitého jílu (většinou s drobnými vápnitými konkrecemi) a méně mocných poloh písků, které byly na makrofaunu velmi bohaté. Vzorky byly odebírány a dokumentovány z jednotlivých fosiliferních poloh. Oryktocenóza obsahovala mělkovodní prvky, např. hermatypní korály, které doposud známe $\mathrm{z}$ moravské části karpatské předhlubně pouze ze zaniklé lokality Jevíčko-Alej (Vašíček 1941). Nově byly fosilie hermatypních korálů z lokality Borač-Podolí studovány Kleprlíkovou (2016).

\section{Systematická část \\ Systematická paleontologie}

Kmen: Mollusca

Třída: Bivalvia LINNAEUS, 1758

Podtř́ida: Heterodonta NEUMAYR, 1884

Čeled: Gastrochaenoidea GRAY, 1840

Rod: Rocellaria BLAINVILLE, 1829

Stratigrafické rozpětí taxonu: Výskyt od eocénu až do recentu (Carter et al. 2008).

Druh: Rocellaria cf. dubia (PENNANT, 1777) (obr. 3b)

1777 Mya dubia, Pennant, str. 69, tab. 44, obr. 19. 1857 Gastrochaena dubia PENNANT, Wood, str. 292-294, tab. 30 (obr. $11 \mathrm{a}-\mathrm{d}$ ).

1900 Gastrochaena dubia PENN., Procházka, str. 118-119. 1939 Gastrochaena dubia PENNANT, Noszky, str. 84, obr. 370 .

1955 Gastrochaena dubia PENN., Sieber, str. 188. 1987 Gastrochaena (Rocellaria) dubia (PENNANT, 1777), Freneix et al., str. 440-441.

1998 Gastrochaena (Gastrochaena) dubia (PENNANT), Schultz, str. 112, tab. 50 (obr. 2-3).

2008 Rocellaria dubia (PENNANT, 1777), Carter et al., str. 107, 108, 114, obr. 10.

2011 Rocellaria dubia, Morton et al., str. 795, obr. 10 .

Materiál: Jedinec byl vyjmut $\mathrm{z}$ kolonie korálu rodu Porites. Popis: Jeden jedinec, schránka 4,5 mm dlouhá. Hladké, neskulpturované misky oválného tvaru. Patrné jsou př́růstkové linie.

Poznámka: Vrtaví mlži z čeledi Gastrochaenoidea využívají mechanické abraze pro vytvoření vrtby za pomoci anteroventrálních oblastí schránky. Jedinec je přichycen $\mathrm{k}$ anteroventrální části své vrtby byssovými vlákny a př́ísavnou nohou, což znamená, že plochy schránky, kde dochází k abrazi, mohou představovat pouze ventrální okraje schránky (Morton et al. 2011). Carter (1978) poukazuje na to, že tato oblast nese znaky obroušení. Carter a Aller (1975) a Carter (1978) rovněž prokázali u některých gastrochaenidů přítomnost aragonitových periostrakálních jehlic, které pravděpodobně u některých druhů podporují 


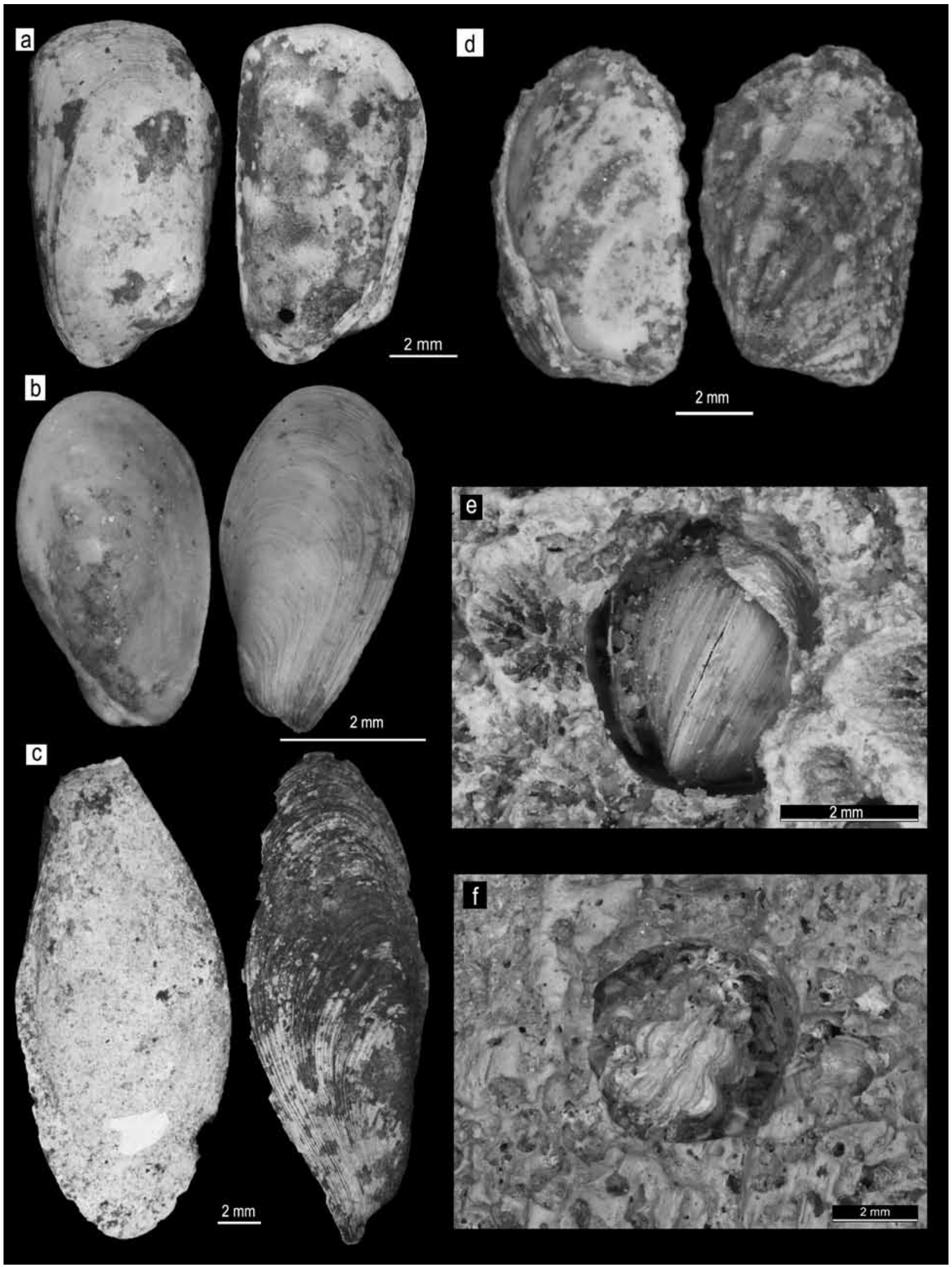

Obr. 3: a - Hiatella arctica LINNAEUS, 1767; b - Rocellaria cf. dubia PENNANT, 1777; c - Gastrochaena cf. intermedia HÖRNES, 1859; d - Cardita calyculata LINNAEUS, 1758; e - Hiatella arctica in situ v korálu rodu Tarbellastraea; - Cardita calyculata in situ ve fragmentu silnostěnné ústřice.

Fig. 3: a - Hiatella arctica LINNAEUS, 1767; b - Rocellaria cf. dubia PENNANT, 1777; c - Gastrochaena cf. intermedia HÖRNES, 1859; d - Cardita calyculata LINNAEUS 1758; e - Hiatella arctica in situ in a coral colony of genus Tarbellastraea; $\mathrm{f}$ - Cardita calyculata in situ in a fragment of thick-shelled oyster. 
vrtavou činnost okraje schránky. Dnes žijí tito měkkýši v hloubce $40-50 \mathrm{~m}$ pod hladinou Jaderského moře (Morton et al. 2011).

\section{Rod: Gastrochaena SPENGLER, 1783}

Stratigrafické rozpětí taxonu: Výskyt s jistotou od eocénu do recentu, možná dříve (jura, křída) - (Carter et al. 2008).

Druh: Gastrochaena cf. intermedia HÖRNES, 1859 (obr. 3c)

1859 Gastrochaena intermedia HÖRN., Hörnes, str. 4-5, tab. 1/3 (obr. a-d).

1870 Gastrochaena intermedia HÖRNES, Wolf, str. 33. 1900 Gastrochaena intermedia HÖRN., Koch, str. 127, obr. 2.

1928 Gastrochaena intermedia HÖRN., Bobies, str. 48. 1942 Gastrochaena intermedia HÖRN., Toth, str. 516. 1981 Gastrochaena intermedia HOERN., Krach, str. 16. 1998 Gastrochaena (G.) intermedia HÖRNES, Studencka et al., str. 310-311, obr. 399.

Materiál: Obě misky byly vyseparovány z vlastní vrby ichnodruhu Gastrochaenolites lapidicus (KELLY et BROMLEY, 1984) z kolonie korálu rodu Porites.

Popis: Misky jsou dlouhé 22,5 mm a 10,0 mm široké. Jsou téměř hladké, s patrnými př́růstkovými liniemi.

rád: Adapedonta COSSMANN et PEYROT, 1909

Čeled: Hiatellidae GRAY, 1824

Rod: Hiatella BOSC, 1801

Stratigrafické rozpětí taxonu: První zástupci tohoto rodu jsou známi z triasu Ruska (Kurushin 1992).

Druh: Hiatella arctica (LINNAEUS, 1767)

(obr. 3a, 3e)

1767 Mya arenaria, Linnaeus, str. 1113, obr. 32. 1877 Saxicava arctica LINN., Karrer, str. 111, 136, 304. 1910 Saxicava arctica LINN., Cottreau, str. 547. 1942 Saxicava arctica LINN., Toth, str. 516, 527. 1966 Hiatella (s. s.) arctica LINNÉ, 1767; Glibert, Van de Poel, str. 24-25.

1972 Hiatella arctica LINNAEUS, 1767; Jakubowski, str. 105-110, tab. 10 (obr. 1-36).

1974 Hiatella arctica LINNÉ, 1767; Abbott, str. 541, obr. 6019.

1975 Hiatella arctica LINNÉ, 1767; Van den Bosch et al., str. 81, obr. 26-29.

1976 Hiatella (Hiatella) arctica L.; Brambilla, str. 125, tab. 31 (obr. 22-23).

1977 Hiatella arctica LINNAEUS, 1767; Jakubowski, Musiał, str. 105. tab. 12, (obr. 8-9).

1998 Hiatella (Hiatella) arctica (LINNAEUS), Studencka et al., obr. 401.
Materiál: Dva artikulované páry misek byly vyseparovány z kolonií rodu Stylophora a jeden z korálu rodu Tarbellastrea, kde tvořily vrtbu ichnotaxonu G. lapidicus. Větší počet jedinců ponechán v korálových koloniích.

Popis: Jedinci o délce 4,5-9,7 $\mathrm{mm}$ a šírce 2,5-6,0 $\mathrm{mm}$. Schránky jsou hladké, někdy s patrnými př́růstkovými liniemi.

Poznámka: Dnes tyto měkkýše známe například ze západního pobřeží Irska, kde jsou typičtí pro hlubší intertidální až mělčí sublitorální zóny (Trudgill, Crabtree 1987).

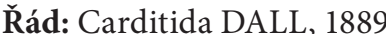

Čeled: Carditidae FÉRUSSAC, 1822

Rod: Cardita BRUGUIËRE, 1792

Stratigrafické rozpětí taxonu: První výskyty toho rodu mlže známe z triasu (Markevich, Zakharov 2004).

Druh: Cardita calyculata LINNEAUS, 1758

(obr. 3d, 3f)

1758 Chama calyculata, Linnaeus, str. 692, obr. 134. 1860 Cardita calyculata L., Reuss, str. 250-251, obr. 95. 1865 Cardita calyculata LINN., Hörnes, 274-275, tab 36/7 (obr. a-c).

1900 Cardita calyculata L., Koch, 129, obr. 121.

1950 Beguina (Mytilicardita) calyculata L., Sieber, str. 306, 308,310

1960 Beguina (Arcinella) calyculata (LINNEAUS 1758), Kojumdgieva, Strachimirov, 48-49, tab. 16, obr. 1-2.

1981 Beguina (Arcinella) calyculata (LINNAEUS 1758) Krach, str. 26, tab. 10, obr. 11.

1993 Cardita calyculata LINNÉ, 1758, Popov et al., str. 98, obr. 179

1998 Cardita calyculata (LINNAEUS), Studencka et al., str. 302-303, obr. 214.

Materiál: Dva jedinci nalezeni ve vrtbách v silnostěnných schránkách ústřic, jeden v korálu rodu Porites.

Popis: Vyseparované schránky jsou dlouhé $8,5 \mathrm{~mm}$ a 5,0 mm široké. Schránka nese trny a deset žeber. Patrné jsou také podélné prŕrůstkové linie.

\section{Systematická ichnologie}

Ichnorod: Gastrochaenolites LEYMERIE, 1842

1842 Gastrochaenolites LEYMERIE, str. 2, tab. 3 (obr. $1 \mathrm{a}-\mathrm{c}$ ).

1972 Trypanites MÄGDEFRAU; Bromley, str. 96, obr. 1 (a, c-d).

1980 Gastrochaenolites LEYMERIE; Kelly, str. 771, (obr. 2 a-g, 3 a-d; tab. 96, obr. 17-20, 22-24).

1980 Gastrochaenolites LEYMERIE; Kelly in Balson, str. 726.

Diagnóza: Kelly a Bromley (1984) popisují tyto ichnofosilie jako kyjovité vrtby v pevném (litifikovaném) substrátu. Oblast ústí vrtby je užší než hlavní komůrka a může být oválná, kulatá nebo činkovitého tvaru. Ústí může být odděleno od hlavní komůrky oblastí krčku, která může 
být široce rozšířená. Hlavní komůrka může být subsférická až protáhlá, mající parabolickou až zaoblenou zkrácenou bázi a kruhový až oválný průřez, modifikovaný u některých forem podélným hřebenem nebo drážkami, což vede $k$ vytvoření mandlovitého nebo srdčitého tvaru $\mathrm{v}$ příčném řezu.

Popis: Vrtby gastrochaenolitního typu jsou často mechanicky erodované při ústích, a proto neurčitelné. To je způsobeno povahou substrátu, ve kterém jsou vrtby vytvořeny. Pouze do rodu bylo možné zařadit 1008 vrteb na 320 bioklastech.

Poznámka: Dnes již známe vrtby ichnorodu Gastrochaenolites také z částečně zpevněných substrátů - firmgroundů (Mikuláš, Žítt 2003; Carmona et al. 2007).

Stratigrafické rozpětí ichnotaxonu: V geologickém záznamu se ichnotaxon Gastrochaenolites objevuje od ordoviku (Bromley 2004).

Ichnodruh: Gastrochaenolites dijugus KELLY et BROMLEY, 1984

(obr. 4a)

Diagnóza: Kelly a Bromley (1984) popisují tento taxon jako gastrochaenolitní vrtbu zúženou v oblasti krčku s činkovitým průřezem.

Popis: Pět vrteb v úlomcích korálů rodu Stylophora a Tarbellastraea. Vrtby v substrátu tvořeném úlomky rodu Tarbellastraea dosahují délky $11 \mathrm{~mm}$. Ústí činkovitého tvaru měří $3 \times 1 \mathrm{~mm}$ a šířka obývací komůrky je $4 \mathrm{~mm}$. Řezy jsou orientovány svisle nebo téměř svisle a protínají úplně nebo z velké částí celou plochu vrtby. Vrtby v úlomcích korálu rodu Stylophora vykazují obdobné rozměry otvoru jako v substrátu rodu Tarbellastraea $(1,5 \times 1-2,5 \times 1 \mathrm{~mm})$. Jedna vrtba je určená pouze podle morfologie ústí, druhá má kolmým řezem odkrytou téměř celou obývací komůrku o šírce $4 \mathrm{~mm}$ a délce vrtby $13 \mathrm{~mm}$.

Poznámka: Jedna z vrteb ichonotaxonu G. dijugus neodpovídá svou orientací růstovému směru korálu (Tarbellastraea) - je orientována kolmo na růstový směr kolonie.

Ichnodruh: Gastrochaenolites lapidicus KELLY et BROMLEY, 1984

(obr. 4b)

Diagnóza: Hladká, kyjovitá vrtba, protáhle oválná. Příčný průřez kruhovitý po celé délce mimo oblast krčku, kde bývá většinou oválný (ale může být i kruhový). Báze je tupě parabolická v podélném řezu, nejširší průřez se nachází přibližně v centru hlavní komůrky (Kelly, Bromley 1984).

Popis: Vrtby se vyskytují napříč všemi druhy koloniálních korálů zastoupených na lokalitě. Jde o kyjovité vrtby, většinou vertikální nebo semivertikální o velikosti mezi 4-32 $\mathrm{mm}$ na délku. Z těchto vrteb byly vyseparovány schránky druhu Gastrochaena cf. intermedia a Hiatella arctica.

Poznámka: Některé vrtby vytvořené na koloniích rodu Porites nemají zachované ústí. To bylo pravděpodobně erodováno při transportu. Nejvíce determinovaných vrteb tohoto typu se nachází na korálech rodu Porites (11). Dalších šest pochází z kolonií rodu Tarbellastraea a 3 z rodu Stylophora.

Ichnodruh: Gastrochaenolites orbicularis KELLY et BROMLEY, 1984

(obr. 4d)

Diagnóza: Hladká vrtba Gastrochaenolites, která je kruhová v př́čném řezu, hlavní komůrka je kulovitá, oblast krčku je protažená, ale může být krátká (Kelly, Bromley 1984).

Popis: Vrtba je vyvrtána v kolonii korálu rodu Tarbellastraea (1 ks). Téměř kulovitá vrtba měří $10 \mathrm{~mm}$ na délku. Vlastní komůrka dosahuje velikosti $5 \mathrm{~mm}$ v průměru a krček je dlouhý $4 \mathrm{~mm}$. Velikost ústí je $1 \mathrm{~mm}$. Vrtba je odkryta podélným řezem na rozlomené kolonii korálu vedeným po celé délce vrtby.

Ichnodruh: Gastrochaenolites torpedo KELLY et BROMLEY, 1984

(obr. $4 \mathrm{e}$ )

Diagnóza: Protažená hladká vrtba s nejširším bodem blízko ke středové linii s bází ostře parabolickou. Oblast krčku je značně zkrácená, přičný průřez vchodovou částí je oválný nebo má tvar čísla osm (Kelly, Bromley 1984).

Popis: Jedná se o větší počet vrteb v úlomcích schránek ústřic a na korálových koloniích. Často nejsou vrtby kompletní, což je pravděpodobně způsobeno mechanickou erozí. Vrtby jsou různých velikostí, ale většinou se pohybují mezi prvními centimetry.

\section{Diskuze a závěr}

Determinované druhy mlžů, které byly nalezeny in situ ve vrtbách gastrochaenolitního typu (Hiatella arctica, Gastrochaena cf. intermedia, Cardita calyculata a Rocellaria cf. dubia), pravděpodobně nemůžeme všechny považovat za původce vlastních vrteb. Zástupci čeledi Gastrochaenoidea GRAY jsou většinou provažováni za primární tvůrce vrteb (Kelly 1980). Mlži druhu Hiatella arctica naopak volí svou životní strategii na základě prrítomného substrátu. Mladí jedinci, kteří se usadí na rovném povrchu relativně měkké homogenní skály, budou vrtaví; jedinci, kteří nacházejí útočiště na tvrdém a nehomogenním povrchu, se přichytí pomocí byssových vláken (Hunter 1949). S jistotou nelze říci, zda jedince nalezené na lokalitě Borač-Podolí můžeme považovat za vrtavé nebo ne. Kelly (1980) popisuje již jurské zástupce tohoto rodu, kteří v nemalém počtu př́padů obsazují vrtbu, kterou evidentně sami nevytvořili. V takovém př́padě jsou potom přichyceni byssovými vlákny na bázi vrtby. Sensu Hunter (1949) můžeme mlže druhu Hiatella arctica z lokality Borač-Podolí považovat za pravděpodobné primární tvůrce vrteb. Naopak u mlže druhu Cardita calyculata není popsán žádný případ recentních či fosilních zástupců, kde by byly pozorovány náznaky vrtavého chování. Z toho důvodu můžeme předpokládat, že se jedná o znovuobsazení starší vrtby, tzv. squatting 

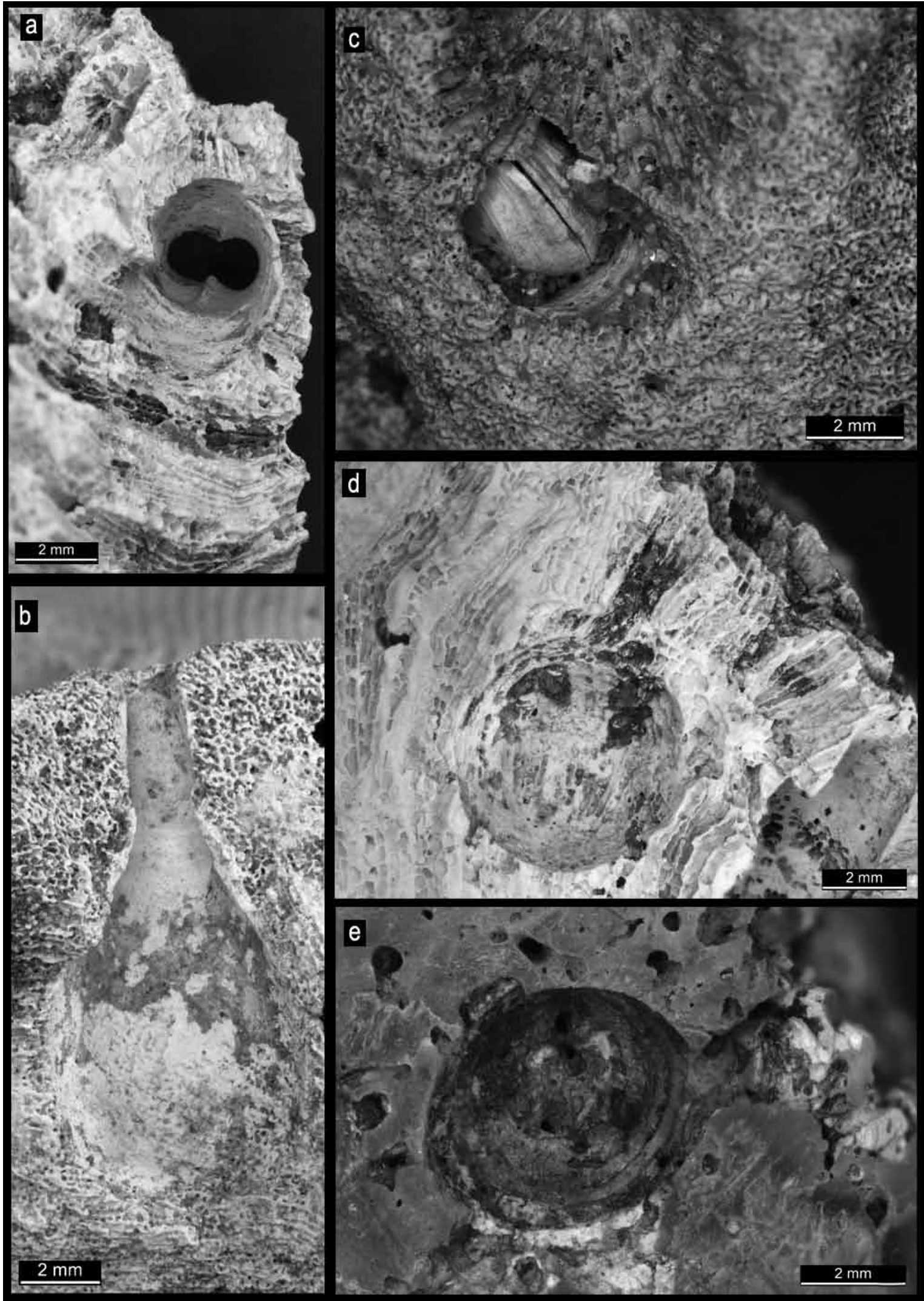

Obr. 4: a - Gastrochaenolites dijugus KELLY et BROMLEY, 1984 v korálu rodu Tarbellastraea; b - Gastrochaenolites lapidicus KELLY et BROMLEY, 1984 v korálu rodu Porites; c - Rocellaria cf. dubia PENNANT, 1777 in situ v korálu rodu Porites; d - Gastrochaenolites orbicularis KELLY et BROMLEY, $1984 \mathrm{v}$ korálu rodu Tarbellastraea; e - Gastrochaenolites torpedo KELLY et BROMLEY, $1984 \mathrm{v}$ úlomku silnostěnné ústřice.

Fig. 4: a - Gastrochaenolites dijugus KELLY et BROMLEY, 1984 bored in a coral of genus Tarbellastraea; b - Gastrochaenolites lapidicus KELLY et BROMLEY, 1984 bored in a coral of genus Porites; c - Rocellaria cf. dubia PENNANT, 1777 in situ in a coral of genus Porites; d - Gastrochaenolites orbicularis KELLY et BROMLEY, 1984 in a coral of genus Tarbellastraea; e - Gastrochaenolites torpedo KELLY et BROMLEY, 1984 in a fragment of thick-shelled oyster shell. 
(Bromley 1996). Původce jednotlivých vrteb nemůžeme bezpečně přiřadit $\mathrm{k}$ vlastním vrtbám, jelikož morfologie vrteb je např. u druhu Rocellaria dubia značně variabilní (Casoli et al. 2016). Jednotlivé morfotypy gastrochaenolitů můžeme považovat za jednotlivé fáze vytváření a prohlubování doupat vrtavých mlžů. Je nepravděpodobné, že by každá čeled’ vrtavých mlžů vytvářela morfologicky odlišné vrtby. Toto tvrzení dokazuje fakt, že čeled’ Gastrochaenidae známe od spodní jury (Carter 1878), ale první vrtby ichnorodu Gastrochaenolites jsou známy již od ordoviku (Bromley 2004).

Dle všesměrné orientace vrteb na koloniích korálů můžeme usuzovat, že vrtby byly vytvořeny až po odumřní korálu. Kusy kolonií byly pravděpodobně ulomeny vlněním a následně obydleny vrtavými organismy. Tyto bioklasty byly podle všeho rotovány vlněním, a proto jsou vrtby po celém povrchu korálových kolonií. Podobně vytvářené bioklasty byly popsány Wilsonem et al. (1998) z jurských sedimentů Utahu, kde pevný substrát vytvářejí akumulace ústřic.

$\mathrm{Na}$ základě charakteru stř́ídání sedimentů odkrytých sondou (obr. 2) můžeme předpokládat, že byl materiál následně přenesen do hlubokovodnějšího prostředí jakožto tempestit (obdobný charakter sedimentace popisuje Nehyba et al. 2008), kde byl zakonzervován. To patrně také napomohlo k zachování mlžů in situ.

\section{Poděkování}

Předložené výsledky byly získány v rámci výzkumného zámèru Geologického ústavu AVČR, v.v.i., č. RVO 67985831 a za podpory Specifického výzkumu ÚGV MU. Autoři by rádi poděkovali recenzentưm a také osazenstvu redakce za prínosné pripomínky, které vedly ke zkvalitnění textu. Dále bychom chtěli poděkovat Mgr. Lucii Kleprlíkové za pomoc prí focení vzorkü.

\section{Literatura}

Abbott, R. T. (1974). American Seashells: The Marine Mollusks of the Atlantic and Pacific Coasts of North America. - 2. vyd., 663 pp. New York.

Augusta, J. (1938). Příspěvek k poznání činnosti vrtavých mlžů z moravského neogénu. - Vlastenecký spolek musejní, 51, 166 -167. Balson, P. S. (1980). The origin and evolution of Tertiary phosphorites from eastern England. - Journal of Geological Society London, 137, 723-729. https://doi.org/10.1144/gsigs.137.6.0723

Blainville, H. M. D. (1829). Dictionnaire des Sciences Naturelles dans lequel on Traite Méthodiquement des Différens Êtres de la Natur, Considérés soit en Eux-mêmes, d'après l'état Actuel de nos Connaissances, soit Relativement a l'Utilité qu'en Peuvent Retirer la Médecine, l'Agriculture, le Commerce et les Arts. Suivi d'une Biographie des Plus Célèbres Naturalistes. - Strasbourg, 557 pp. - Paris.

Bobies, K. A. (1928). Das Gaadener Becken. Mitteilungen der Geologischen Gesellschaft. - 19, 47-78.

Bosc, L. A. G. (1801). Histoire naturelle des coquilles, contenant leur description, les moeurs des animaux qui les habitent et leurs usages. Paris.

Bosch, Van den M., Cadée M. C., Janssen A. W. (1975). Lithostratigraphical and biostratigraphical subdivision of Tertiary deposits (Oligocene-Pliocene) in the Winterswiik-Almelo region (eastern part of the Netherlands). - Scripta Geologica, 29. 1-167.

Brambilla, G. (1976). I Molluschi pliocenici di villalvernia (Allesandria) I. Lamellibranchi. - Memorie della Società Italiana di Scienze Naturali del Museo Civico di Storia Naturale Milano, 21, 81-128.

Bromley, R. G. (1972). On some ichnotaxa in hard substrates, with a redefinition of Trypanites MÄGDEFRAU. - Paläontologische Zeitschrift, 1/2, 93-98. https://doi.org/10.1007/BF02989555

Bromley, R. G. (1996). Trace Fossils. Biology, taphonomy and applications, - 2. vyd. 361 pp. Chapman \& Hall. London, Glasgow, Weinheim, New York, Tokyo, Melbourne, Madras.

Bromley, R. G. (2004). A stratigraphy of marine bioerosion. - In: McIlroy, D. (ed.): The application of Ichnology to Palaeoenvironmental and Stratigraphic analysis. Geological Society, Special Publications, 228, 455-479. London.

Bruguière, J. G. (1792). Catalogues des coquilles envoyées de Cayenne, à la Société d'Histoire Naturelle de Paris. - Actes de la Société d'Histoire Naturelle de Paris, 1, 1-126.

Carmona, N. B., Mángano, M. G., Buatois, L. A., Ponce, J. J. (2007). Bivalve trace fossils in an early Miocene discontinuity surface in Patagonia, Argentina: Burrowing behavior and implications for ichnotaxonomy at the firmground-hardground divide. - Palaeogeography, Palaeoclimatology, Palaeoecology, 255, 239-341.

Carter, J. G. (1978). Ecology and evolution of the Gastrochaenacea (Mollusca, Bivalvia) with notes on the evolution of the endolithic habitat. - Bulletin of the Peabody Museum of Natural History, 41, 1-92.

Carter, J. G., Aller, R. C. (1975). Calcification in the bivalve periostracum. - Lethaia, 8, 315-320.

Carter, J. G., McDowell, T., Namboodiri, N. (2008). The identity of Gastrochaena cuneiformis SPENGLER, The evolution of Gastrochaena, Rocellaria, and Lamychaena (Mollusca, Bivalvia, Gastrochaenoidea). - Journal of Paleontology, 82, 102-117.

Casoli, E., Ricci, S., Antonelli, F., Perasso, C. S., Belluscio, A., Ardizzone, G. (2016). Impact and colonization dynamics of the bivalve Rocellaria dubia on limestone experimental panels in the submerged Roman city of Baiae (Naples, Italy). - Internation biodeterioration \& Biodegradation, 108, 9-15. https://doi.org/10.1016/j.ibiod.2015.11.026

Cossmann, M., Peyrot, A. (1909). Conchologie Néogénique de l’Aquitaine. - Actes de la Société linnéenne de Bordeaux, 63, 73-293.

Cottreau, J. (1910). Les argiles de Baden (Autriche) et les marnes de Cabrières d'Aigues (Vaucluse). - Bulletin de la Société Géologique de France, 10, 541-557. 
Dall, W. H. (1889). Reports on the results of dredgings, under the supervision of Alexander Agassiz, in the Gulf of Mexico (1877-78) and in the Caribbean Sea (1879-80), by the U. S. Coast Survey steamer "Blake," Lieut. Commander C. D. Sigsbee, U. S. N., and Commander J. R. Bartlett, U. S. N., commanding. XXIX. Report on the Mollusca. Part II. Gastropoda and Scaphopoda. - Bulletin of the Museum of Comparative Zoology, 18, 1-492.

Férussac, A. E. J. P. J. F. d'Audebard de (1821-1822). Tableaux systématiques des animaux mollusques classés en familles naturelles, dans lesquels on a établi la concordance de tous les systèmes; suivis d'un prodrome général pour tous les mollusques terrestres ou fluviatiles, vivants ou fossiles. $-47,27,110$, Paris.

Freneix, S., Saint-Martin, J.-P., Moisette, P. (1987). Bivalves Hétérodontes du Messinien d'Oranie (Algérie occidentale). - Bulletin du Muséum d'Histoire Naturelle, 9/C/4, 415-453.

Glibert, M., Van de Poel, L. (1966). Les bivalvia fossiles du Cénozoique étranger des collections de l'Institu Royal des Scinces naturalles de Belgique. - Mémoires de l'Institut Royal des Sciences Naturelles de Belgique, 81, 1-82.

Gray, J. E. (1824). On the natural arrangement of the pulmonobranchous Mollusca. - Annals of Philosophy, 8, 107-109.

Gray, J. E. (1840). Eastern Zoological Gallery. Synopsis of the Contents of the British Museum, 42, 89-156.

Hörnes, M. (1859-1867). Die fossilen Mollusken des Tertiär-Beckens von Wien, Band II Bivalven. - Abhandlungen der Geologischen Reichsanstalt, 4, 430 pp. Wien.

Hudec, P. (1986). Systematická a paleoekologická analýza měkkýšů badenu na lokalitě Lomnice u Tišnova. - MS, diplomová práce. Př́rodovědecká fakulta J. E. Purkyně. Brno.

Hunter, W. R. (1949). The structure and behavior of Hiatella gallicana (LAMARCK) and H. arctica L. with special reference to the boring habits. - Proceedings of the Royal Society of Edinburgh, řada B, 63, 271-289. https://doi.org/10.1017/ S0080455X00011930

Jakubowski, G. (1972). Ontogeny of some pelecypod shells from the Miocene of Poland. - Prace Muzeum Ziemi, 20, 45-115.

Jakubowski, G., Musiał, T. (1977). Lithology and fauna from the Upper Tortonian sands of Monastyrz and Dlugi Goraj (Southern Roztocze - Poland). - Prace Muzeum Ziemi, 26. 63-126.

Janoška, M., Mikuláš, R., Pek, I. (1995). Stopy vrtavých badenských organismů na vápencových rockgroundech z Černotína (severní Morava). - Časopis Slezského zemského muzea Opava (A), 44, 97-99.

Karrer, F. (1877). Geologie der Kaiser Franz Josefs Hochquellen Wasserleitung. Eine Studie in den Tertiär-Bildungen am Westrande des alpinen Theiles der Niederung von Wien. - Abhandlungen der Geologischen Reichsanstalt, 9, 420 pp. Wien.

Kelly, S. R. A. (1980). Hiatella - A Jurassic squatter? - Palaeontology, 23, 769-781.

Kelly, S. R. A., Bromley, R. G. (1984). Ichnological nomenclature of clavate borings. - Paleontology, 27, 4, 793-807.

Kleprlíková, L. (2016). Anthozoa vybraných lokalit badenu jižní Moravy. - MS, diplomová práce, Př́rodovědecká fakulta Masarykovy univerzity. Brno.

Koch, A. (1900). Die Tertiärbildungen des Beckens der siebenbürgischen Landestheile. - 370 pp. Budapest.

Kojumdgieva, E., Strachimirov, B. (1960). Tortonien. - Les Fossiles de Bulgarie, 7, 317 pp. Sofia.

Krach, W. (1981). Badenskie utwory rafowe na Roztoczu Lubelskim. - Prace geologiczne, 121, 5-115. Warszawa.

Kurushin, N. I. (1992). Triasovye Paleogeterodontnye i Geterodontnye Dvustvorski Sibiri. - Trudy instituta Geologii i Geofiziki. 742, 1-86. Moskva.

Lehotský, T., Jašková, V. (2005). Nové lokality s výskytem stop vrtavých organismů na střední Moravě. - In: Lehotský, T. (ed.): 6. paleontologický semináŕ, Sborník př́spěvků, 38-39. Univerzita Palackého v Olomouci.

Leymerie, A. (1842). Suite du mémoire sur le terraion crétacé du Département de l'Aube. Second partie. - Mémoires de la Société géologique de France, 5, 1-34. Paris.

Linnaeus, C. (1758). Systema naturae per regnatria naturae, secundum Classes, Ordines, genera, species, cum characteribus, differentiis, synonymis, locis. Editio Decima, Reformata, Tom I. - 824 pp. Holmiae.

Linnaeus, C. (1767). Systema Naturae. ed.12-13, 1328 pp. Vindobona.

Markevich, P. V., Zakharov, Y. D. (2004). Trias i Yura Sikhote-Alinya, kniga 1: Terrigennyy kompleks. - 412 pp. Moskva.

Mikuláš, R., Pek, I., Hladil, J. (1999). Bioerosive traces in the Badenian corals from Jevíčko, Eastern Bohemia, Czech Republic. Zemní plyn a nafta, 43, 3, 443-457. Hodonín.

Mikuláš, R., Pek, I. (1995). Tertiary borings in Devonian limestone rockgrounds from Hranice (northern Moravia, Czech Republic). - Věstník Českého geologického ústavu, 70, 1, 19-26.

Mikuláš, R., Žítt, J. (2003). The ichnogenus Gastrochaenolites and its tracemakers from firmgrounds of the Bohemian Cretaceous Basin (Czech Republic). - Ichnos 10, 1, 15-23. https://doi.org/10.1080/10420940390235080

Morton, B., Peharda, M., Petrić, M. (2011). Functional morphology of Rocellaria dubia (Bivalvia: Gastrochaenidae) with new interpretations of crypt formation and adventitious tube construction, and a discussion of evolution within the family. Biological Journal of the Linnean Society, 104, 786-804. https://doi.org/10.1111/j.1095-8312.2011.01763.x

Nehyba, S., Tomanová Petrová, P., Zágoršek, K. (2008). Sedimentological and palaeocological records of the evolution of the southwestern part of the Carpathian Foredeep (Czech Republic) during the early Badenian. - Geological Quarterly, 52, 1, 45-60.

Neumayr, M. (1884). Zur Morphologie des Bivalvenschlosses. - Sitzungsberichte der Akademie der Wissenschaften zu Wien, $88,1,385-418$.

Noszky, J. (1939). Die Molluskenfauna des Kisceller Tones (Rupelian) us der Umgebung von Budapest. I Teil. Lamellibranchiata. - Annales Historico-Naturales Musei Nationalis Hungarici, 32, 19-164.

Pek, I., Mikuláš, R. (1996). Traces of boring activity of organisms on marlite cobbles at Česká Třebová (Miocene, lower Badenian, Czech Republic). - Věstník Českého geologického ústavu, 71, 3, 285-290.

Pek, I., Zapletal, J., Janoška, M. (1998). Stopy vrtavé činnosti organismů na spodnobadenských valounech od Čelechovic na Hané. - Zemní plyn a nafta, 43, 1, 153-161.

Pek, I., Mikuláš, R. (1999). Stopy vrtavé činnosti organizmů badenského stáří od Mikulova. - Zemní plyn a nafta, 43, 4, 599 -623. 
Pennant, T. (1777). British Zoology - 4 (Crustacea. Mollusca. Testacea). - 156 pp. London.

Popov, S. V., Voronina, A. A., Goncharova, I. A. (1993). Oligocene-Lower Miocene Stratigraphy and Bivalves of the Eastern Paratethys. - Trudy Paleontologicheskogo instituta, 256, 206 pp. Moskva.

Procházka, V. J. (1900). Das Ostböhmische Miocean. - Archiv für die naturwissenschaftliche Landesdurchforschung Böhmens, Geologische Section, 10, 173 pp. Praha.

Reuss, A. E. (1860). Die marinen Tertiärschichten Böhmens und ihre Versteinerungen. Sitzungsberichte der Kaiserlichen Akademie der Wissenschaften. - Wien Mathematisch-naturwissenschaftliche Classe. Abteilung 1, 39, 207-285.

Schultz, O. (1998). Tertiärfossilien Österreichs. - Goldschneck-Verlag, 159 pp. Wien.

Seitl, L. (1978). Stratigraficky významné druhy měkkýšů lokality Borač. - MS, diplomová práce, Př́rodovědecká fakulta J. E. Purkyně. Brno.

Sieber, R. (1950). Die mittelmiozänen Crassatellidae, Carditidae und Cardiidae des Wiener Beckens. Anzeiger der Österreichische Akademie der Wissenschaften. - Mathematisch- naturwissenschaftliche Klasse, 11, 304-311.

Sieber, R. (1955). Systematische Übersicht der jungtertiären Bivalven des Wiener Beckens. - Annalen des naturhistorischen Museums in Wien. Serie A, 60, 161-201. Wien.

Spengler, L. (1783). Lorentz Spenglers Beskrivelse over en nye Slægt af tos - kallede Muskeler, som kan kaldes Gastrochaena, i tre foranderlige Arter, hvoraf hver boer i et forskielligt Ormehus. Nye Samling af det Kongelige Danske Videnskabers Selskabs Skrifter. - 2, 174-183.

Studencka, B., Gontsharova, I., Popov, S. (1998). The bivalve faunas as a basis for reconstruction of the Middle Miocene history of the Paratethys. - Acta Geologica Polonica, 48, 285-342.

Toth, G. (1942). Paläobiologische Untersuchungen über die Torton-fauna der Gaadener Bucht. - Palaeobiologica, 7, 496-530.

Trudgill, S. T., Crabtree, R. W. (1987). Bioerosion of intertidal limestone, co. Clare, Eire - 2: Hiatella arctica. - Marine Geology, 74, 99-109.

Vašíček, M. (1941). Geneze a ráz tortonských sedimentů v okolí Jevíčka. - Zprávy geologického ústavu, 17, 6, 323-334.

Wilson, M. A., Ozanne, C. R., Palmer, T. J. (1998). Origin and Paleoecology of Free-Rolling Oyster Accumulations (Ostreoliths) in the Middle Jurassic of Southwestern Utah, USA. - Palaios, 13, 70-78. https://doi.org/10.2307/3515282

Wolf, H. (1870). Die Stadt Oedenburg und ihre Umgebung. - Jahrbuch der Geologischen Reichsanstalt, 20, 1, $15-64$.

Wood, S. V. (1851-1857). A Monograph of the Crag Mollusca with description of shells from the Upper tertiaries of the British Isles - 2 (Bivalves). - 342 pp. London

Editor: Pavla Tomanová Petrová

Doporučená citace článku: Šamánek, J., Mikuláš, R., Doláková N., Hladilová, Š. (2018). Vrtby ichnorodu Gastrochaenolites jakožto životní prostor mlžů z lokality Borač-Podolí (karpatská předhlubeň, Česká republika). - Geologické výzkumy na Moravě a ve Slezsku, 25, 1-2, 49-57. 